\title{
Penghambatan Produksi Aflatoksin dari Aspergillus flavus oleh Kapang dan Khamir yang Diisolasi dari Ragi Tempe
}

\section{Inhibition of Aflatoxin Production of Aspergillus flavus by Moulds and Yeasts Isolated from Ragi Tempe}

\section{Ekawati Purwijantiningsih ${ }^{*}$, Ratih Dewanti-Hariyadi ${ }^{2}$, C.C. Nurwitri ${ }^{2}$ dan Istiana $(\text { alm. })^{3}$}

${ }^{1}$ Fakultas Biologi Universitas Atma Jaya Yogyakarta. e-mail: e_purwiyanti@yahoo.com * penulis untuk korespondensi

${ }^{2}$ Departemen Teknologi Pangan dan Gizi, Fakultas Teknologi Pertanian, Institut Pertanian Bogor.

3 Balai Penelitian Veteriner, Bogor

\begin{abstract}
This research was carried out to study the inhibition of aflatoxin production of Aspergillus flavus by moulds and yeasts isolated from ragi tempe. The result showed that moulds found in the ragi tempe consisted of Rhizopus oligosporus, $R$. oryzae, $R$. cohnii, Mucor rouxii, Rhizomucor pusillus, Aspergillus niger and miselia sterilia. Yeasts found in the samples were Candida sp1, Candida sp2 and Trichosporon sp. Twelve mould, and yeast isolates were chosen to determine their ability on inhibition of aflatoxin production. Aspergillus flavus alone or in association with each of these isolates were inoculated in Potato Dextrose Broth and analysed for aflatoxin production at day 10 . All combinations yielded less aflatoxin than the single culture of A. flavus. All isolates tested could inhibit aflatoxin production. The highest inhibition was shown by Candida sp1 $(99,96 \%)$.
\end{abstract}

Key words : inhibition, aflatoxin, Aspergillus flavus, biocontrol, ragi tempe

Diterima : 12 Mei 2005, disetujui : 13 Juni 2005

\section{Pendahuluan}

Aflatoksin merupakan senyawa metabolit sekunder dari kapang Aspergillus flavus, A. parasiticus, dan A. nomius yang banyak mengkontaminasi berbagai jenis komoditi pertanian seperti kacang-kacangan, jagung, beras, tanaman palawija lainnya serta hasil olahannya. Aflatoksin juga ditemukan pada bahan pakan dan pakan ternak sebagai penyebab terjadinya aflatoksikosis dan residu aflatoksin pada produk peternakan. Pembentukan aflatoksin oleh kapang tersebut sulit dihindari karena iklim tropis di Indonesia dengan tingkat kelembaban yang tinggi, curah hujan dan suhu tinggi sangat menunjang pertumbuhan dan perkembangbiakkan kapang penghasil aflatoksin (Sutikno et al., 1993; Bhatnagar et al., 2000).

Aflatoksin dapat menyebabkan kerusakan hati akut, sirosis hati, induksi tumor dan efek teratogenik (Pitt and Hocking, 1997). Menurut Noer (2002) pada tahun 1991, Rumah Sakit Cipto Mangunkusumo (RSCM) melaporkan bahwa 20\% kasus kanker hati tidak berkorelasi dengan infeksi hepatitis B maupun hepatitis $\mathrm{C}$, namun diduga disebabkan oleh aflatoksin $B_{1}$. Aflatoksin juga menyebabkan aflatoksikosis pada produk peternakan. Huff et al., (1986) melaporkan aflatoksin dapat menyebabkan penurunan berat badan, peningkatan berat limfa dan ginjal, serta terjadinya atropi pada hati sampai hepatomegaly pada ayam broiler. 
Selain berbahaya bagi kesehatan, aflatoksin mengakibatkan kerugian ekonomi yang cukup besar dan berpengaruh terhadap perdagangan internasional. Kerugian yang disebabkan oleh cemaran mikotoksin, terutama aflatoksin di Asia mencapai 400 juta dolar per tahun (Zanelli, 2000), sedangkan di Australia mencapai 10 juta dolar per tahun (Pitt and Hocking, 1997).

Berdasarkan penelitian yang telah dilakukan, diketahui banyak komoditas pertanian di Indonesia memiliki kandungan aflatoksin melebihi ambang batas yang ditetapkan (Dharmaputra, 2002). Batas maksimum kandungan aflatoksin yang diperbolehkan dalam makanan dari FDA di Amerika Serikat yakni 20 ppb untuk makanan ternak dan 15 ppb untuk konsumsi manusia (Pitt and Hocking, 1997). Mengingat kerugian dan bahaya yang ditimbulkan oleh aflatoksin, maka perlu dilakukan suatu upaya penanggulangan yang efektif.

Penanggulangan secara fisik dapat menyebabkan hilangnya zat-zat gizi pada bahan pangan, sedangkan penambahan zat-zat kimia tidak mudah dilakukan pada bahanbahan yang dikonsumsi manusia. Pendekatan lain untuk mengendalikan kontaminasi aflatoksin adalah penggunaan agen kontrol biologis, yaitu mikrob kompetitor atau antagonis untuk menghambat pertumbuhan $A$. flavus ataupun menghambat biosintesis aflatoksin.

Pada ragi tempe dijumpai beberapa jenis kapang dan khamir yang bersifat nontoksigenik. Isolat-isolat dari ragi tempe yang berpotensi sebagai biokompetitor $A$. flavus dan kemampuannya dalam menghambat produksi aflatoksin belum pernah dilaporkan. Penelitian ini merupakan penelitian awal yang bertujuan untuk mengetahui isolat-isolat kapang dan khamir yang berperan dalam menghambat produksi aflatoksin A. flavus sehingga dapat digunakan untuk mengatasi masalah kontaminasi aflatoksin pada bidang pertanian, peternakan serta pangan.

\section{Metode Penelitian}

Penelitian dilakukan di Laboratorium Mikologi dan Toksikologi Balai Penelitian Biota Vol. X (3), Oktober 2005
Veteriner Bogor pada bulan Mei 2003 hingga Januari 2004. Ragi tempe dikumpulkan dari berbagai daerah yakni DKI Jakarta, Jawa Barat (Bogor), Jawa Tengah (Purwokerto), Yogyakarta dan Jawa Timur (Malang). Kapang toksigen yang digunakan dalam penelitian ini yakni Aspergillus flavus 713 yang diperoleh dari Laboratorium Mikologi Balai Penelitian veteriner.

\section{Isolasi Kapang dan Khamir (Daulay, 1989)}

Sebanyak $5 \mathrm{~g}$ ragi tempe ditambah dengan $45 \mathrm{ml}$ akuades steril, setelah itu dilakukan pengenceran dari $10^{-1}$ sampai dengan $10^{-7}$. Satu $\mathrm{ml}$ suspensi ragi tempe dimasukkan ke dalam cawan Petri diameter $9 \mathrm{~cm}$, kemudian 15-20 ml medium APDA (Potato Dextrose Agar (Oxoid) + asam tartarat 10\% sebanyak $10 \mathrm{ml} / 1$ ) yang suhunya $\pm 40^{\circ} \mathrm{C}$ dituang ke dalam cawan tersebut lalu diratakan, setelah itu diinkubasi selama dua hari pada suhu kamar. Setiap koloni kapang dan khamir yang berbeda warna dan penampilannya dipisahkan dan dimurnikan, selanjutnya dibiakkan pada PDA miring untuk digunakan sebagai sediaan kultur.

\section{Pembuatan Kultur Slide (Harrigan, 1998)}

Untuk membuat kultur slide dibutuhkan cawan Petri yang di dalamnya terdapat kaca obyek yang diletakkan di atas batang $\mathrm{U}$ atau V, perangkat tersebut berada dalam keadaan steril. Potongan medium PDA steril berukuran 1x1 cm diletakkan di atas kaca obyek yang berada di dalam cawan Petri, setelah itu dilakukan inokulasi kapang pada potongan medium tepat di tengah-tengah keempat sisinya menggunakan ujung jarum ose.

Potongan agar-agar yang telah diinokulasi kemudian ditutup dengan kaca penutup. Akuades steril dituangkan ke dalam cawan Petri tanpa membasahi kaca obyek yang ada di dalamnya, selanjutnya kultur slide diinkubasi pada suhu kamar sampai terjadi sporulasi. Bila spora telah muncul, kaca penutup diangkat dan diletakkan pada kaca obyek lain yang telah diberi cairan pewarna lactophenol cotton blue, kemudian struktur kapang diamati di bawah mikroskop. 


\section{Identifikasi Isolat Kapang (Pitt and Hocking, 1997)}

Identifikasi isolat kapang dilakukan baik secara makroskopik maupun mikroskopik. Identifikasi secara makroskopik dilakukan dengan cara melihat langsung koloni yang tumbuh pada medium Czapek Yeast Extract Agar (CYA), Malt Extract Agar (MEA) dan 25 Gyserol Nitrate Agar (G25N) setelah dua hari inkubasi pada suhu ruang. Koloni yang tumbuh akan mempunyai spora dengan bentuk dan warna yang berbeda-beda tergantung dari spesies kapang, sedangkan identifikasi secara mikroskopik dilakukan dengan cara mengamati struktur kapang dengan mikroskop berskala setelah sebelumnya ditumbuhkan dalam kultur slide selama tiga hari.

Untuk menentukan spesies kapang, ciriciri makroskopik dan mikroskopik yang dimiliki isolat kapang dibandingkan ciri-ciri kapang yang terdapat pada pustaka acuan "A Manual of Soil Fungi" (Gilman, 1957) dan "Fungi and Food Spoilage" (Pitt and Hocking, 1997). Konfirmasi spesies kapang dilakukan di Laboratorium Fitopatologi, SEAMEO BIOTROP Bogor.

\section{Identifikasi Khamir}

Identifikasi khamir dilakukan berdasarkan morfologi dan sifat fisiologis dengan melakukan beberapa uji seperti uji asimilasi, fermentasi gula-gula serta kemampuan pertumbuhan khamir pada suhu $37^{\circ} \mathrm{C}$ dan kemampuan membentuk pati ekstraseluler. Hasil pengamatan morfologi dan uji fisiologis kemudian dicocokkan dengan ciri-ciri khamir pada pustaka "Yeast Characteristic and Identification" (Barnett et al., 2000) dan "The Yeasts: A Taxonomic Study" (Lodder, 1974).

\section{Morfologi Khamir (Lodder, 1974)}

Isolat khamir digoreskan pada permukaan medium Corn Meal Agar (CMA, Difco) lalu ditutup dengan kaca penutup dan diinkubasi pada suhu kamar selama tiga hari. Bagian sisi atau tepi dari koloni yang tumbuh diamati di bawah mikroskop dengan perbesaran $400 \mathrm{x}$ untuk melihat ada tidaknya miselium (semu atau sejati), blastospora, dan artrospora.

\section{Uji Fermentasi Gula (Lodder, 1974)}

Tabung miring berisi medium PDA diinokulasi dengan khamir lalu diinkubasi selama dua hari pada suhu kamar, kemudian secara aseptis dibuat suspensi khamir dengan menambah $10 \mathrm{ml}$ akuades steril ke dalam tabung. Medium fermentasi gula di dalam tabung diinokulasi dengan menambahkan 0.1 $\mathrm{ml}$ suspensi khamir. Setelah dikocok, medium diinkubasi pada suhu kamar. Pada hari ke-3, 7 dan 14 dilakukan pengamatan terhadap pembentukan asam (perubahan warna indikator $\mathrm{pH})$ dan pembentukan gas di dalam tabung Durham. Gula-gula yang diuji adalah dekstrosa, galaktosa, laktosa, maltosa, rafinosa, sukrosa, dan trehalosa.

\section{Uji Asimilasi Karbon (Lodder, 1974)}

Sebanyak $1 \mathrm{ml}$ suspensi khamir dituang ke dalam cawan Petri, kemudian ditambahkan medium Yeast Nitrogen Base (YNB, Difco) + agar noble sebanyak $15-20 \mathrm{ml}$. Setelah membeku, sebanyak $5 \mathrm{mg}$ gula-gula yang akan diuji ditaburkan secara terpisah. Selanjutnya diinkubasi pada suhu kamar dan diamati pada hari ke-3 dan 7 untuk mengetahui ada tidaknya pertumbuhan yang menunjukkan sumber karbon tersebut diasimilasi atau tidak oleh khamir yang diuji. Gula-gula yang diuji adalah dekstrosa, galaktosa, laktosa, maltosa, rafinosa, sukrosa, dan trehalosa.

\section{Uji Pertumbuhan pada Suhu $3^{\circ} \mathrm{C}$ (Lodder, 1974)}

Isolat khamir digoreskan pada tabung yang berisi medium PDA dan diinkubasi pada suhu $37^{\circ} \mathrm{C}$ untuk menentukan kemampuan tumbuh khamir pada suhu tersebut.

\section{Uji Kemampuan Membentuk Pati Ekstraseluler (Lodder, 1974)}

Isolat khamir digoreskan pada cawan Petri yang mengandung medium PDA dan diinkubasi pada suhu kamar selama tiga hari, selanjutnya pada biakan isolat ditetesi larutan iod untuk mengetahui kemampuan khamir membentuk pati. Apabila terbentuk warna biru, maka khamir tersebut membentuk pati.

Biota Vol. X (3), Oktober 2005 


\section{Persiapan Spora Kapang dan Sel Khamir (Kim et al., 2000)}

Kultur murni kapang dan khamir hasil isolasi diremajakan dengan cara menggoreskan kembali kultur murni tersebut pada medium PDA miring yang baru, kemudian kapang diinkubasi pada suhu kamar selama tujuh hari, sedangkan khamir selama dua hari. Suspensi spora kapang dibuat dengan menambahkan akuades steril yang mengandung $0.1 \%$ Tween 80 ke dalam agar miring, sedangkan khamir tanpa Tween 80 . Suspensi akhir diatur sampai konsentrasinya sekitar $10^{6}$ spora/ ml. Perhitungan spora dilakukan dengan menggunakan hemasitometer.

\section{Uji Aktivitas Isolat Kapang dan Khamir terhadap Penghambatan Produksi Aflatoksin (Modifikasi Sardjono et al., 1992)}

Sebanyak $0.5 \mathrm{ml}$ suspensi spora A. flavus dengan konsentrasi $10^{6} \mathrm{spora} / \mathrm{ml}$ dicampur dengan $0.5 \mathrm{ml}$ suspensi spora kapang atau sel khamir yang akan diuji dengan konsentrasi $10^{6}$ spora atau sel $/ \mathrm{ml}$, diinokulasikan ke dalam 100 ml medium Potato Dextrose Broth (PDB, Oxoid) dan diinkubasi selama 10 hari pada suhu kamar. Sebagai kontrol $0.5 \mathrm{ml}$ suspensi spora A. flavus $\left(10^{6} \mathrm{spora} / \mathrm{ml}\right)$ diinokulasi ke dalam medium PDB, kemudian diinkubasi pada waktu dan kondisi yang sama. Setelah itu dilakukan analisis kandungan aflatoksin dan dihitung reduksi aflatoksin dari isolat kapang atau khamir uji dibandingkan dengan kandungan aflatoksin pada kontrol.

\section{Ekstraksi Aflatoksin (Heathcot, 1984)}

Sebanyak $10 \mathrm{ml}$ filtrat dari isolat yang ditumbuhkan pada PDB ditambahkan dengan $10 \mathrm{ml}$ kloroform, lalu diblender selama dua menit selanjutnya dikocok selama 30 menit, setelah itu dimasukkan ke dalam labu pemisah sehingga terbentuk dua lapisan yaitu lapisan atas dan lapisan bawah (kloroform). Lapisan bawah yang mengandung aflatoksin disaring melalui Natrium sulfat bebas air, kemudian larutan ekstrak ini diuapkan dengan menggunakan rotary evaporator. Residu yang ada dilarutkan kembali menggunakan kloroform. Hasil ekstraksi tersebut selanjutnya dianalisis untuk mengetahui kandungan aflatoksinnya.

\section{Analisis Aflatoksin (AOAC, 1995)}

Pada penelitian ini analisis aflatoksin dengan menggunakan Kromatografi Lapis Tipis satu dimensi dengan fase gerak I kloroform : aseton $=9: 1$. Untuk konfirmasi aflatoksin digunakan dengan TLC dua dimensi dengan fase gerak II yakni etil asetat : toluena : asam format $=5: 4: 1$. Plat TLC yang digunakan adalah plat dengan fase diam silica gel 60 (MERCK). Tahap identifikasi dilakukan dengan cara menyuntikkan cairan sampel dan larutan standar (secara kuantitatif) pada lempeng kromatografi. Setelah itu lempeng kromatografi dielusi di dalam bejana fase gerak I kloroform : aseton $=9: 1$, kemudian dikeringkan dengan pengering rambut. Hasil elusi yang telah dikeringkan diamati di bawah lampu UV dengan panjang gelombang $365 \mathrm{~nm}$. Rate of flow (Rf) dari fluoresensi bercak sampel dan standar dibandingkan. Aflatoksin dikatakan positif jika $\mathrm{Rf}$ sampel sama dengan standar (deteksi aflatoksin secara kualitatif).

Kandungan aflatoksin pada sampel (deteksi aflatoksin secara semi kuantitatif) diperoleh dengan membandingkan intensitas fluoresensinya dengan standar. Hal tersebut diperoleh dari deret aflatoksin yang dielusi dengan fase gerak I dan kandungan aflatoksin ditentukan menggunakan rumus sebagai berikut:

Kandungan aflatoksin $(\mathrm{ppb})=\frac{\mathrm{SxYxVxFp}}{\mathrm{WxZ}}$

Keterangan :

$\mathrm{S}$ :Volume aflatoksin standar $(\mu \mathrm{l})$ yang memberikan perpendaraan setara dengan $\mathrm{Z} \mu \mathrm{l}$ sampel

Y:Konsentrasi aflatoksin standar dalam $\mu \mathrm{g} / \mathrm{ml}$

Z:Volume ekstrak sampel yang dibutuhkan untuk memberikan perpendaran setara dengan $S \mu l$ standar aflatoksin

$\mathrm{V}$ :Volume pelarut yang digunakan untuk melarutkan sampel ekstrak akhir $(\mu \mathrm{l})$

$\mathrm{W}$ :Volume sampel (ml)

Fp:Faktor pengenceran 
Penghambatan produksi aflatoksin dihitung dengan rumus sebagai berikut:

$$
\% \text { penghambatan }=\stackrel{\mathrm{A}-\mathrm{B}}{\mathrm{A}} \times 100 \%
$$

A

Keterangan:

A:Konsentrasi aflatoksin yang dihasilkan oleh $A$. flavus pada medium PDB

B:Konsentrasi aflatoksin yang dihasilkan oleh $A$. flavus yang dikultur bersama isolat kapang atau khamir dari ragi tempe pada medium PDB

\section{Hasil dan Pembahasan}

\section{A. Isolasi dan Identifikasi Kapang dan Khamir dari Ragi Tempe}

$\begin{array}{llll}\text { Identifikasi kapang dari ragi tempe } \\ \text { dilakukan secara mikroskopis } & \text { untuk }\end{array}$

mengetahui morfologi kapang menggunakan metode kultur slide yang dilengkapi dengan pengamatan makroskopis. Berdasarkan kunci identifikasi Pitt and Hocking (1997) penggolongan ordo Mucorales ke dalam genus berdasarkan pada bentuk kolumela dan ukuran spora, selanjutnya penggolongan Rhizopus ke dalam spesies berdasarkan pada perkembangan rizoid, ukuran spora, sporangiofor serta kolumela. Sedangkan menurut Gilman (1957) penggolongan Mucor ke dalam spesies berdasarkan ukuran sporangium dan ukuran sporangiospora, warna hifa serta suhu optimum pertumbuhan. Karakterisasi isolat kapang dari ragi tempe dapat dilihat pada Tabel 1 .

Tabel 1. Karakterisasi isolat kapang ragi tempe

\begin{tabular}{|c|c|}
\hline Karakterisasi isolat kapang & Hasil identifikasi kapang \\
\hline $\begin{array}{l}\text { Hifa berseptum, konidia dibentuk oleh fialid yang terletak di atas metula, } \\
\text { terdapat di seluruh permukaan vesikel, konidia berwarna hitam, diameter } \\
\text { koloni lebih dari } 50 \mathrm{~mm} \text { pada medium CYA }\end{array}$ & Aspergillus niger \\
\hline Miselium seperti benang-benang tipis, tidak menghasilkan spora aseksual. & Miselia sterilia \\
\hline $\begin{array}{l}\text { Diameter sporangium kurang dari } 100 \mu \mathrm{m} \text {, berwarna putih sampai coklat emas, } \\
\text { tumbuh pada suhu } 37^{\circ} \mathrm{C} \text {, spora } 4-5 \mu \mathrm{m} \text {, kolumela berbentuk bulat. }\end{array}$ & Mucor rouxii \\
\hline $\begin{array}{l}\text { Kolumela berbentuk payung, rizoid sedikit atau kurang berkembang, pada } \\
\text { sporangiofor tidak menggembung, panjang sporangiofor kurang dari } 150 \mu \mathrm{m} .\end{array}$ & Rhizopus cohnii \\
\hline $\begin{array}{l}\text { Kolumela berbentuk payung, tidak memproduksi zigospora, pertumbuhan } \\
\text { cepat pada suhu } 37^{\circ} \mathrm{C} \text {, diameter spora kurang dari } 8 \mu \mathrm{m} \text {, diameter kolumela } \\
75 \mu \mathrm{m} \text {. }\end{array}$ & Rhizopus oligosporus \\
\hline $\begin{array}{l}\text { Rizoid berkembang dengan baik, tidak memproduksi zigospora, pertumbuhan } \\
\text { cepat pada suhu } 37^{\circ} \mathrm{C} \text {, kolumela berbentuk payung dengan diameter lebih dari } \\
100 \mu \mathrm{m} \text {. }\end{array}$ & Rhizopus oryzae \\
\hline $\begin{array}{l}\text { Rizoid tidak berkembang dengan baik, kadangkala tidak muncul dari bagian } \\
\text { dasar sporangiofor, kolumela berbentuk bulat, berwarna coklat keabuan, } \\
\text { diameter spora jarang melebihi } 5 \mu \mathrm{m} \text {. }\end{array}$ & Rhizoтисоr pusillus \\
\hline
\end{tabular}

Penggolongan khamir ke dalam spesies dapat dilakukan berdasarkan sifat morfologi dan fisiologis. Pada penelitian ini, pengamatan khamir dilakukan terhadap morfologi dan uji sifat fisiologis khamir yang meliputi uji asimilasi, fermentasi gula-gula dan kemampuan tumbuh pada suhu $37^{\circ} \mathrm{C}$ serta membentuk pati ekstraseluler (Tabel 2). Identifikasi spesies khamir secara lengkap dilakukan dengan uji-uji lainnya seperti uji asimilasi $\mathrm{N}$, kebutuhan vitamin, kemampuan menghasilkan amilase, pembentukkan pigmen, produksi ester, produksi asam asetat, hidrolisis urea, pertumbuhan pada medium dengan tekanan osmotik tinggi serta reaksi dengan diazonium blue (Barnett et al., 2000; Lodder, 1974). 
Tabel 2. Karakterisasi isolat khamir

\begin{tabular}{lc}
\hline \hline Karakterisasi isolat khamir & Hasil identifikasi khamir \\
\hline \hline Sel tumbuh membentuk pseudomiselium, dapat tumbuh pada suhu $37^{\circ} \mathrm{C}$, & Candida sp1 \\
tidak membentuk pati ekstraseluler, dapat melakukan fermentasi pada & \\
dekstrosa, galaktosa, maltosa, sukrosa dan trehalosa, dapat melakukan & \\
asimilasi pada dekstrosa, galaktosa, maltosa, sukrosa, trehalosa. & \\
Sel tumbuh membentuk pseudomiselium, dapat tumbuh pada suhu $37^{\circ} \mathrm{C}$, & Candida sp2 \\
tidak membentuk pati ekstraseluler, tidak dapat melakukan proses & \\
fermentasi, dapat melakukan asimilasi pada dekstrosa, galaktosa, maltosa, & \\
sukrosa, dan trehalosa. & Trichosporon sp. \\
Sel tumbuh membentuk artrospora, dapat tumbuh pada suhu 37 C, tidak \\
membentuk pati ekstraseluler, tidak dapat melakukan proses fermentasi, \\
dapat melakukan asimilasi pada dekstrosa, galaktosa, laktosa, maltosa, \\
rafinosa, sukrosa, dan trehalosa.
\end{tabular}

Secara lengkap hasil yang diperoleh dari isolasi dan identifikasi kapang serta khamir yang berasal dari ragi tempe dapat dilihat pada Tabel 3. Kapang yang sering dijumpai adalah Rhizopus oligosporus, selain itu juga dijumpai $R$. oryzae, R. cohnii, Mucor rouxii, Rhizomucor pusillus (Mucor pusillus), Aspergillus niger, dan miselia sterilia.

Genus Rhizopus, Mucor, dan Rhizomucor termasuk dalam ordo Mucorales. Ketiga genus tersebut merupakan kapang tidak berseptum, memiliki struktur reproduksi aseksual yang disebut sporangiospora, terdapat di dalam sporangium. Aspergillus niger merupakan kapang berseptum, konidia dibentuk oleh fialid yang terletak di atas metula, terdapat di seluruh permukaan vesikel. Pada medium CYA, koloni A. niger berdiameter lebih dari $50 \mathrm{~mm}$, koloni berwarna hitam. Pada vesikel terdapat metula dan fialid (Pitt and Hocking, 1997). Kapang lain yang dijumpai yakni miselia sterilia. Jika dilihat di bawah mikroskop, penampakan miselium tersebut hanya seperti benang-benang tipis.

Tabel 3. Hasil isolasi dan identifikasi kapang dan khamir dari ragi tempe

\begin{tabular}{lll}
\hline \hline Asal daerah & Nama ragi & Kapang dan khamir \\
\hline \hline Jakarta & Raprima & Rhizopus oligosporus \\
Bogor & Raprima & $R$. oligosporus \\
Purwokerto & Biang Premix & $R$. oligosporus, A. Niger \\
& Gamma & $R$. oligosporus \\
& Parabola & $R$. oligosporus, . oryzae, A. Niger \\
& Payung & $R$. oligosorus, Rhizomucor pusillus, Mucor rouxii \\
& Tiga Berlian & $R$. oligosorus, Mucor rouxii \\
& Usar daun jati & Candida sp1, Candida sp2, Trichosporon sp., miselia sterilia \\
Yogyakarta & Usar daun Jati & $R$. oligosporus \\
& Usar daun waru & $R$. oligosporus \\
Malang & Usar daun waru & $R$. cohnii \\
\hline \hline
\end{tabular}

Khamir yang ditemukan adalah Candida sp1, Candida sp2 dan Trichosporon sp. Sel Candida tumbuh membentuk pseudomiselium yang mengandung banyak sel-sel tunas atau disebut blastospora, sedangkan Trichosporon membentuk artrospora (Lodder, 1974).

Spesies khamir hanya ditemukan pada usar daun jati yang berasal dari Purwokerto, sedangkan pada usar lainnya tidak ditemukan adanya khamir. Hal tersebut dapat disebabkan karena usar daun jati yang berasal dari Purwokerto adalah usar yang baru dibuat, sedangkan usar yang lain tidak diketahui secara pasti waktu pembuatannya. Menurut Jutono (1985) viabilitas mikrob pada usar dapat bertahan selama 4 - 6 minggu jika disimpan pada suhu ruang, sedangkan jika disimpan pada suhu $4^{\circ} \mathrm{C}$ akan bertahan lebih dari 24 minggu. 
Beberapa penelitian yang dilakukan pada usar yang baru dibuat menunjukkan adanya khamir pada usar tersebut.

Samson et al., (1987) melaporkan bahwa pada 110 sampel tempe, kapang dan khamir yang sering dijumpai adalah $R$. oryzae, $R$. oligosporus, M. indicus, Trichosporon beigelii, Candida lusitaniae, $C$. maltosa dan $C$. intermedium. Pada tempe ditemukan beberapa spesies khamir, oleh karena usar dibuat dengan meletakkan tempe pada permukaan daun, maka pada usar yang belum terlalu lama waktu pembuatannya akan ditemukan berbagai spesies khamir.

\section{B. Kemampuan Isolat Kapang dan Khamir dalam Menghambat Produksi Aflatoksin}

Pengujian kemampuan isolat kapang dan khamir dalam menghambat produksi aflatoksin dilakukan pada dua belas isolat yang berasal dari ragi tempe. Berdasarkan analisis kandungan aflatoksin diketahui bahwa produksi aflatoksin menurun dibandingkan kontrol.

Kapang dan khamir yang diisolasi dari ragi tempe memiliki kemampuan yang bervariasi dalam menghambat produksi aflatoksin (Tabel 4). Rhizopus cohnii memiliki kemampuan terendah dalam menghambat produksi $\mathrm{AFB}_{1} 45 \%, \mathrm{AFB}_{2}$ yakni sebesar $19.23 \%$, dan total aflatoksin sebesar $37.21 \%$, sedangkan Candida sp1 memiliki kemampuan tertinggi yakni $\mathrm{AFB}_{1} 99.95 \%, \mathrm{AFB}_{2} 99.98 \%$, dan total aflatoksin sebesar $99.96 \%$. Penurunan kadar aflatoksin dapat disebabkan karena terhambatnya pertumbuhan A. flavus dan/ ataupun karena terhambatnya biosintesis aflatoksin.

Tabel 4 . Penghambatan produksi aflatoksin oleh isolat kapang dan khamir yang berasal dari ragi tempe

\begin{tabular}{|c|c|c|c|c|c|}
\hline \multirow[t]{2}{*}{ NO. } & \multirow[t]{2}{*}{ Cendawan } & \multirow[t]{2}{*}{ Ragi } & \multicolumn{3}{|c|}{ Persentase penghambatan aflatoksin } \\
\hline & & & $\overline{\mathbf{A F B}_{1}}$ & $\overline{\mathbf{A F B}_{2}}$ & Total \\
\hline 1. & Aspergillus niger & Biang Premix & 82.50 & 90.00 & 87.44 \\
\hline 2. & Candida sp1 & Usar daun jati & 99.95 & 99.98 & 99.96 \\
\hline 3. & Candida sp2 & Usar daun jati & 89.84 & 92.22 & 95.56 \\
\hline 4. & Mucor rouxii & Tiga Berlian & 80.00 & 48.28 & 71.15 \\
\hline 5. & Rhizoтисог pusillus & Payung & 99.17 & 98.95 & 99.15 \\
\hline 6. & Rhizopus cohnii & Usar daun waru & 45.00 & 19.23 & 37.21 \\
\hline 7. & R. oligosporus & Gamma & 51.25 & 62.50 & 54.65 \\
\hline 8. & R. oligosporus & Raprima & 47.20 & 46.00 & 46.86 \\
\hline 9. & R. oligosporus & Usar daun jati & 70.00 & 82.69 & 73.84 \\
\hline 10. & R. oligosporus & Usar daun waru & 60.00 & 65.38 & 61.63 \\
\hline 11. & R. oryzae & Parabola & 55.00 & 52.63 & 54.31 \\
\hline 12. & Trichosporon sp. & Usar daun jati & 97.00 & 96.57 & 96.88 \\
\hline
\end{tabular}

Rhizopus oligosporus yang berasal dari ragi tempe yang berbeda memiliki kemampuan yang berbeda dalam menghambat produksi aflatoksin. Kemampuan tersebut bervariasi antara $46.86-73.84 \%$. Menurut Suzzi et al., (1995) aktivitas biokontrol tidak sepenuhnya tergantung pada spesies atau genus melainkan setiap galur memiliki karakteristik yang spesifik.

\section{Kesimpulan}

Kapang yang sering dijumpai pada ragi tempe adalah Rhizopus oligosporus. Dua belas isolat kapang dan khamir yang diisolasi dari ragi tempe memiliki kemampuan yang bervariasi dalam menghambat produksi aflatoksin. Rhizopus cohnii memiliki kemampuan terendah dalam menghambat produksi total aflatoksin sebesar $37.21 \%$, sedangkan Candida sp1 memiliki kemampuan tertinggi yakni sebesar $99.96 \%$. 


\section{Ucapan Terima Kasih}

Penulis mengucapkan terima kasih kepada Kepala Balai Penelitian Veteriner, Bogor dan Kelti Laboratorium Toksikologi yang telah memberikan kesempatan kepada penulis untuk melaksanakan penelitian ini. Penelitian ini terlaksana dengan dukungan bahan, sarana dan prasarana dari Balai Penelitian Veteriner. Ucapan terima kasih juga disampaikan kepada Dra. Romsyah Maryam M.Sc, Drh. Jainudin Gholib, Dr. R. Widiastuti, B.Sc dan Eni Kusumaningtyas, M.Sc serta para teknisi di Laboratorium Mikologi dan Toksikologi atas bantuan selama penelitian.

\section{Daftar Pustaka}

AOAC (Association of Official Analytical Chemist), 1995. Natural poison. In: Hoewitz, W. (ed.) Official Methods Analysis of The Association of Official Analytical Chemists $11^{\text {st }}$ ed. Assosiation of Analytical Chemist. Washington DC.

Barnett, J.A., Payne R.W. and Yarrow, D. 2000. Yeast Characteristic and Identification. $3^{\text {th }}$ ed. Cambridge University Press, Cambridge.

Bhatnagar, D., Cleveland, T.E. and Payne, G.A. 2000. Aspergilus flavus. In: Robinson, R.K., Batt, C.A., and Patel, P.A. (Eds.). Encyclopedia of Food Microbiology vol 3. pp. 72-79. Academic Press, New York.

Daulay, D. 1989. Identifikasi Mikroba yang Berperan dalam Fermentasi Tauco. Laporan Penelitian, Laboratorium Mikrobiologi Pangan PAU Pangan dan Gizi IPB, Bogor.

Dharmaputra, O.S. 2002. Review on aflatoxin in Indonesian food and feedstuffs and their products. BIOTROPIA 19: 26-46.

Gilman, J.C. 1957. A Manual of Soil Fungi $2^{\text {nd }}$ ed. The Iowa State College Press, Iowa.

Harrigan, W.F. 1998. Laboratory Methods in Food Microbiology $3^{\text {th }}$ ed. Academic Press, San Diego
Heathcot, J.G. 1984. Aflatoxin and related toxin. In: Betina, V (ed.). Mycotoxins: Production, Isolation, Separation \& Purification. Pp 89126. Elsevier Sci. Publ., Amsterdam.

Huff, W.E., Kubena, L.F., Harvey, L.B., Corrier, D.E. and Mollenhauer, H.H. 1986. Progression aflatoxicosis in broiler chickens. Poultry Science 65: 1891-1899.

Jutono. 1985. The microbial of usar, a traditional tempe inoculum. In: Proceeding of Asian symposium on non-salted soybean fermentation, July 1985. Tsukuba, Japan.

Kim, J.G., Lee, Y.W., Kim, P.G., Roh, W.S. and Shintani, H. 2000. Reduction of aflatoxin by korean soybean paste and its effect on cytotoxicity and reproductive toxicity-part 1 . Inhibition of growth and aflatoxin production of Aspergillus parasiticus by korean soybean paste (doen-jang) and identification of active component. J.Food.Prot. 63: 1295-1298.

Lodder, J. 1974. The Yeast: A Taxonomic Study $2^{\text {nd }} e d$. North-Holland Publ. Comp. Amsterdam.

Noer S. 2002. Ancaman kanker hati dari makanan tercemar jamur. KOMPAS 11 September 2002: 11

Pitt, J.I. and Hocking, A.D. 1997. Fungi and Food Spoilage. Blackie Academic \& Professional. London.

Samson, R.A., Van Kooij, J.A. and De Broer, E. 1987. Microbial quality of commercial tempeh in the Netherlands. J. Food. Prot 50: 92-94.

Sardjono, Rahayu, K. and Sudarmadji, S. 1992. Growth and aflatoxin production by Aspergillus flavus in mixed culture with Aspergillus oryzae. Asean Food Jour. 7: 30-33.

Sutikno, A.I., Haryati, T. dan Suherman, D. 1993. Kontaminasi aflatoksin pada ransum itik. Ilmu \& Peternakan 6 (1): 37-41.

Suzzi, G., Romano, P., Ponti, I. and Montuschi C. 1995. Natural wine yeast as biocontrol agent. $J$. Appl. Bacteriol 78: 304-308.

Zanelli, L. 2000. Moulds, Bacteria and Solutions. Feed Industry Servic, Italy. 